\title{
Flew, Aristotle, and Usury
}

Dennis Taylor

University of Illinois at Urbana-Champaign

In an article entitled,. "The Profit Motive"l Antony Flew defends the notion of a profit motive against those more socialistically minded persons who claim that such a motive is intrinsically selfish and immoral. Flew chooses as the main object of his attack the ancient Greek philosopher Aristotle and in particular the latter's discussion of trade and usury. In what follows, I will argue that Elew 1) has taken passages of Aristotle out of context, 2) has muddled the issue between himself and Aristotle, and 3 ) has failed to establish his own view. I will further provide a reading of Aristotle that is more accurate and philosophically interesting than Flew's and thereby clarify the real issue between Flew and Aristotle.

Flew claims that Aristotle's treatment of economics in the Politics is fraught with three misconceptions: 1) whenever two parties make a trade of good or money one party benefits at the expense of the other, 2) usury is wrong, 3) there is a dichotomy between acquisition for household use and acquisition for financial gain. I will deal with each of these in turn.

To reveal the falsity of the first thesis. Flew quotes Aristotle's Politics:

The natural form therefore of acquisition is always and in all cases, acquisition from fruits and animals. That art . . . has two forms: one which is connected with the management of the household. Of these two forms the latter is necessary and laudible; the former is a method which is justly censured, because the gain in which it results is not naturally made, but is made at the expense of the other man. ${ }^{2}$

Elew's interpretation of this passage is: "Aristotle's point is that trade is in essence exploitation."

There are several problems with Flew's assessment. To begin with, it must be made clear that for Aristotle there were two kinds of trade; one kind he approved of and the other he claimed has led to much economic wrong." Flew, in the above quote, leaves out the word 
'retail' before the word 'trade' and would have us believe that Aristotle was antagonistic toward trade of any kind whatsoever. This is clear from what Flew says by way of elucidating his interpretation of Aristotle: "Aristotle thinks.. . the only credible acquisitions are those achieved from non-human nature direct." the first sentence of the passage Flew quotes does seem to support this assessment. But if we read Aristotle in context we see that he made an explicit affirmation of one kind of non-natural acquisition. In describing the development of society Aristotle says that the fanily developed:

a kind of barter which is still practiced among barbarous nations who exchange with one another the necessaries of life and nothing more; giving and receiving wine, for example, in exchange for corn, and the like. This sort of barter is not part of the wealth-getting art and is not contrary to nature, but is needed for the satisfaction of men's natural wants."

What then can be said about this apparent contradiction in Aristotle's text? The heart of the problem lies in the first sentence from the passage Elew quotes, viz. the one that says that the natural form of acquisition is always from fruits and animals, i.e. from nature. There are several problems with this sentence.

First, the translation Flew uses reads as follows: "The natural form, therefore, of the art of acquisition is always and in all cases, acquisition from fruits and animals." But the phrase' and in all cases' does not appear in the Greek text. The text reads:

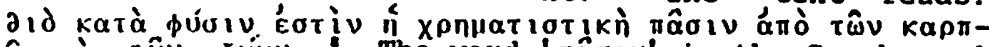

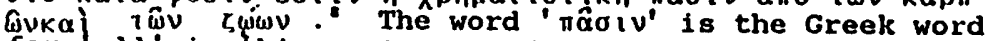
for all' in this sentence and is the only part of this sentence from which the phrase in question could come. But 'all' or even 'always' surely is not equivalent to 'always and in all cases'.

The second problem is that the adverbial form of

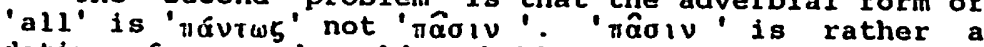
dative form and would probably be better rendered by, 'to all', 'for all', or 'by all'. In fact, H. Rackham, who translates the Politics for the Loeb Classical Library does translate it this way: "Hence the business of drawing provision form the fruits of the soil and from animals is natural to all." In spite of this however, some translators have translated ' adverbially. For example, $W$. D. Ross renders the sentence in question as follows: "Wherefore, the art of getting wealth out of fruits and animals is always natural."10 Benjamin Jowett also translates it adverbially: "Wherefore the art of making money out of fruits and animals is always natural." 1 "Now, there is a special usage of ' $n \alpha S^{\prime}$ in which it can accurately be 
rendered by 'always' whẹn it occurs in the neuter plural. And ' $\alpha \sigma i v$ ' is a dative plural that has identical masculine and neuter forms. So it is possible that Aristotle intended 'naoiv' to be neuter and the translation to read 'always' especially since there are other places where Aristotle does use 'maoiv ' adverbially. Nonetheless, I think a non-adverbial translation is more accurate and thus to be preferred.

The third problem with this sentence is that even if we do translate 'maoiv' as 'always', the statement in and of itself does not say that such acquisitions are the only kind of acquisitions that are proper. We have to go to the rest of what Aristotle says to see, as Flew points out, that Aristotle took the intentions of nature to be normative.

Thus I think Flew is relying on a questionable translation and it's quite possible that there is no contradiction in Aristotle at all. But even if Flew's translation were correct, there is a very natural way of interpreting the whole of Aristotle's discussion so as to eliminate the apparent contradition. We would say that Aristotle looks to acquisition from nature as the ideal form of acquisition that ought to be exemplified whenever possible. Since pragmatic considerations prevent an exact imitation, we allow for a form of barter or trade. This interpretation would be supported by the fact that as one reads the three chapters in the Politics as a whole, it is unclear just how antagonistic Aristotle was toward even retail trade. It looks like Aristotle's only real enemy is usury. Thus, even working with the translation Flew uses, there is an interpretation of Aristotle that would eliminate the apparent contradiction. But unfortunately. Flew does not recognize the problem his translation has with the rest of Aristotle's discussion. Rather, he chooses to ignore this problem and give us an oversimplified and inaccurate account of Aristotle's position.

Another problem with Flew's claim that Aristotle thought trade was always exploitative, is the fact that retail trade was not inherently wrong for Aristotle. Aristotle certainly disliked retail trade and thought that it had led to many wrongs. But he does not say that it is inherently wrong. In fact, when describing the development of society he gives a rather different outlook on retail trade:

When the inhabitants of one country became more dependent on those of another, and they imported what they needed, and exported what they had too much of, money necessarily came into use. For the various necessaries of life are not easily carried about, and hence men agreed to employ in their dealings with each other something which is intrinsically useful and easily applicable to the 
purposes of life, for example iron, silver and the like. 22 (emphases mine)

And later he says:

When the use of coin had once been discovered out of barter of necessary articles arose the other art of wealth-getting, namely, retail trade; which was at first probably a simple matter, but became more complicated as soon as men learned by experience whence. . the greatest profit might be made. ${ }^{13}$

And when Aristotle concludes his discussion of wealthgetting he says: "For molney was intended to be used in exchange, but not to increase at interest." 14 For Aristotle, retail trade is not inherently wrong. If it could be restricted to the level of exchange, devoid of being used to gain interest, there is textual evidence that Aristotle would have no qualms with it. Aristotle's real enemy seems to be usury, not retail trade.

The last problem with Flew's assessment is that he has missed Aristotle's real point. As I stated earlier, Elew claims that Aristotle's attack was aimed at the exploitative nature of trade. But I want to now argue that Aristotle's chief concern with usury and retail trade was not exploitation. In his description of usury in chapter nine, he makes it fairly clear that his opposition to this kind of wealth-getting is that it leads to a quality of life that is in conflict with the 'good life': "The origin of this disposition in men is that they are intent upon living only, and not upon living well."15 Aristotle is arguing that in the practice of usury, money and/or its accumulation becomes an end in itself rather than a means to some other end. But we know from the Nichomachean Ethics that there is only one thing good in itself for Aristotle, viz. the good life (Eúsaluovía). The individual who practices usury has given up the good life for one of greed and consumption, He has lost sight of that for which he was made, his ' $\rho \lambda$ ov $^{\prime}$ and seeks a goal contrary to his nature. In chapter nine Aristotle tells us that when the individual takes up usury he neglects to perform his societal tasks properly:

The quality of courage, for example, is not intended to make wealth, but to inspire confidence; neither is this the aim of the general's or physician's art; but the one aims at victory and the other at health. Nevertheless, some men turn every quality or art into a means of getting wealth; this they conceive to be the end and to the promotion of the end they think all things must contribute. 16 
So when the various individuals in society seek money as an end rather than eúsaluovía they contribute toward the general decline of the society. Feople become inconsiderate of their fellow citizens and are just as likely to cheat them as not. A craftsman produces yoods, the quality of which is of little concern to him, as long as it brings him a nice return. So he not only is prevented from obtaining the good life himself, but is also preventing his fellows from obtaining it. thus contributing to the decline of society. For Aristotle society is given by nature and whatever contributes to its decline is, ipso facto, an enemy of nature. Exploitation in this scenario is of only secondary importance. The chief concern is the good life and the preservation of society, both of which are natural. 17

According to Flew, Aristotle's second misconception is his belief that usury is wrong. Flew tells us that Aristotle's argument against usury is that money, i.e. pieces of metal, can not have progeny, but this is precisely what usury does, it makes money breed itself. Usury then is unnatural and therefore wrong. Aristotle does present this line of reasoning" and while it was not so strange to the Athenian ear, it certainly is strange to us. But as I have just argued, Aristotie had another, more interesting reason for claiming that usury was in opposition to nature, viz. that it leads to a poor quality of life. This reason is not so strange to us. And if Flew had taken it up he might have been more successful against Aristotle. As it is, Elew's objections fall short:

For a sum of money is the substantial equivalent of any of the goods or collections of goods which it might buy. There can, therefore, be nothing obnoxiously unnatural about receiving a money return upon an investment in money, unless it would be equally obnoxious and unnatural to ask for some return either in money or kind for the use of the goods themselves. 20

But this is no reply to Arlstotle. For, even though Aristotle offers no discussion on the charging of rent, it is likely that he would say that charging rent for goods borrowed is just as wrong as charging interest for money borrowed. Toward the end of his article. Flew offers his only defense for the charging of rent: ". . it is hard to see how one could defend the total rejection in principle of the acceptance of rent for the use of (private) property if once one had conceded any right to (private) property at all."12 But this still will not do. Aristotle may just claim that the sole right of private property is possession and this grants no further right of charging rent. 
Flew ignores Aristotle's interesting attack on usury, and thus operates with an overly simplistic conception of what 'nature' means for Aristotle. And this confusion renders his project unsuccessful. If Elew wants to refute Aristotie, he must do one of three things: 1) show that Aristotle's view of nature is incorvect and usury is at least not contrary to it, or 2) affirm Aristotle's notion of nature and show his notion of usury to be incorrect, or 3) show that just because something is unnatural does not necessarily mean that it is inappropriate. But Flew has done none of these. The most Flew does in this regard is to point out that Aristotle's view of nature leads him to some unusual claims, viz. that slavery and war are in accord with nature. These claims may raise doubts as to the credibility of A.ristotle's concept of nature, but they do not, in and of themselves, justify a wholesale rejection of Aristotle's view of nature. Nor do they establish that usury is somehow in accord with nature.

Another problem with Aristotle's second alleged misconception is that Flew implies that Aristotle wanted to abolish money and that such abolition would make men less selfish: "The abolition of money might make us less mercenary. It would not by itself begin to make us less materialistic or less competitive."12 In the three chapters under consideration, Aristotle simply does not say he wants to abolish money. In fact, as we have seen, he appears to favor a certain resticted use of it. What Aristotle did want to abolish was usury. But he made no claim that such abolition would make people less materialistic or competitive. What he does claim is that its abolition would help make possible the good life and the good society.

The third Aristotelian misconception that Flew discusses comes from Aristotle's dichotomy between acquisition for financial gain and acquisition for household use. Flew says: "The antithesis is false for the very reason that there can be no profit in producing what no one has any wish to buy, and presumably, to use." 2 " Now Aristotle says that, ". . the art of household management must either find ready to hand, or itself provide, such things necessary to life, and useful for the community of the family or state. . "24 But Aristotle's emphasis in this chapter is clearly on the needs of the house rather than on things that are useful. Says Aristotle, "Property, in the sense of a bare livelihood, seems given by nature herself to all. "2s And even though Aristotle talks of the householder acguiring things both necessary and useful he is using 'useful' in a different sense than Flew is. For Aristotle, the houselolder's acquisitions have a limit:

"for the amount of property which is needed for a good life is not unlimited.. ." Thus he can not be using 'useful' in the broad sense Flew is, where just 
anything can have some use. What qualifies as useful for Aristotle are things that can be used to get what is needed. Thus I think we can read Aristotle's dichotomy as one between acquisition (or trade) of necessary items and acquisition (or trade) of unnecessary items for the purpose of making a profit. Perlıaps, as Elew says, there is no dichotomy between useful things and profitable things. But, at least on one sympathetic reading, Aristotle claims to make no such dichotomy. Rather. his is between necessary items and profitable ones. And this dichotomy does not seem to be a false one at all.

Nothing I have said in the foregoing commits me to a rejection of Flew's claim that usury is morally permissable, or to the acceptance of Aristotle's claim that usury ought to be censured. What I am committed to is the claim that Flew's interpretation of Aristotle is inaccurate, that this inaccuracy confuses the real issues between Aristotle and Flew, and that Flew fails to adequately establish his own view. I have also claimed that I have provided a more accurate, charitable, and philosophically interesting interpretation which clears the waters Flew has muddied and makes it possible to see what the real issue is between Aristotle and Flew. This interpretation yields the following scenario. Flew favors usury for the reason that it is much like the practice of charging rent which in turn is simply one of the rights of private property. I have suggested that Aristotle could give a ready response to this argument, viz. that the sole right of private property might only be possession. Aristotle dislikes usury, ultimately, because it decreases one's quality of life and contributes toward the disintegration of society. Now let me suggest that Elew no doubt has a ready response to Aristotle, viz. that usury, in fact increases one's quality of life and contributes toward the preservation of society. Taking up the debate suggested by this scenario is the topic of another paper, viz. the paper flew should have written.

\section{NOTES}

'Ethics, (July, 1976), pp. 312-322.

2Ibid.. p. 315, (Flew is quoting here from Ernest Barker's translation of The Politics at 1258a 38-b2).

Ibid. 
Aristotle, The Politics, trans. W. D. Ross in Vol. $x$ of The Works of Aristotle Translated Into Engligh. Book I chpts. 8 and 9 .

sElew, p. 315 .

'Aristotle, trans., Ross, 1257a 24-30.

'Elew, p. 315.

Aristotelis Politica (Oxford: Clarendon Press, $1957), 1258 \mathrm{a} 37 \overline{\mathrm{f}}$.

'Aristotle The Politics, trans., H. Rackham, (London: willian Heinman Ltd., 1932), 1258a 36-38.

${ }^{10}$ Aristotle, trans., Ross, 1258a $36 f$.

"Aristotle's Politics, trans.. Benjamin Jowett (Oxford: Clarendon Press, 1920), 1258a $37 \mathrm{f}$.

12 Aristotle, trans. Ross, 1257a 33-38.

13 Ibid.. 1257b 1-5.

1"Ibid. , 1258b $3 \mathrm{f}$.

"I Ibid., 1257b 41-1258a 1 .

16 Ibid. , 1258a 10-14.

17 Ernest Barker, (Political Thought of Plato and Aristotle, pp. 385-387), ignores the quality of life objection to usury, mentioning only the 'exploitation' objection. But I fail to see the textual justification for this. Besides its coherence with Aristotle's other discusssions of 'nature', my interpretation is corroborated by R. G. Mulgan, Aristotle's Political Theory, pp. $48 \mathrm{f}$.

"Aristotle, trans. Ross, 1258b 2-8.

"See Ernest Barker's discussion on how the ancient Greeks conceived the relation between words and objects in Political Thought of Plato and Aristotle, pp. $385 \mathrm{f}$.

20 Elew, p. 318 .

2 'Ibid. , p. 321 .

22 Ibid. , p. 318 .

${ }^{23}$ Ibid.. p. 319.

"Aristotle, trans., Ross, 1256b 28ff. 
${ }^{25}$ Ibid. , 1256b $8 f$.

${ }^{26}$ Ibid. , 1256b $31 f$. 